\title{
Allotment Garden Dwellings: Exploring Tradition and Legal Framework
}

\author{
Maja Lorbek \\ Milena Martinsen
}

\author{
Maja Lorbek, Leibniz Institute of Ecological Urban and Regional Development \\ Weberplatz 1, 01217 Dresden, Germany (m.lorbek@ioer.de) \\ Milena Martinsen, Leibniz Institute of Ecological Urban and Regional Development \\ Weberplatz 1,01217Dresden, Germany(m.martinsen@ioer.de)
}

\begin{abstract}
At the end of $19^{\text {th }}$ century, the removal of city walls and introduction of mass transport in European cities provided the opportunity to expand cities in green suburban areas. Colonies of small houses with garden plots and allotment gardens developed during this era thus represent a new type of settlement, where green infrastructure (gardens) and allotment dwellings are closely intertwined. The gardens in these settlements were originally based on the notion of subsistence economy, providing food and emergency accommodation in periods of crisis. This paper examines the evolution of allotments and particularly allotment dwellings in Germany and Austria by matching the actual practices of gardeners with the formation of and changes in the legal framework. The legislation and zoning regulations, which were predominantly established after the fact, reveal an ongoing process of negotiation between informal practices and planning authorities.
\end{abstract}

Keywords: allotment gardens, ecosystem services, allotment dwelling, informal practice, legal framework

\section{Introduction}

The emergence of allotment gardening occurred simultaneously in the mid and late nineteenth century in several European countries (Segers \& Van Molle, 2014, DeSilvey, 2003; Crouch \& Ward, 1997; Spilková \& Vágner, 2016). At the turn of the century, allotment garden holders were already organized in several national federations and in 1927 the "Office international des jardins ouvriers" was formed (Katsch \& Walz, 2001). During the initial period, allotments were fruit and vegetable gardens with the goal to provide self-grown food but also to enable healthy outdoor activities during leisure time (Katsch \& Walz, 2001) (Gallati, Mischa \& Schiller, Janine, 2011). They also counterbalanced overcrowded and precarious multi-storey dwellings in expanding industrial cities such as Vienna and Berlin (Kampffmeyer, 1926, Kuhn, 2006).

Currently, gardening activities in urban agglomerations, from traditional allotments and urban agriculte to contemporary community gardening are increasingly recognized as an important part of urban green infrastructures with considerable, yet not fully empirically investigated impact on microclimatic conditions, rainwater management, biodiversity and participatory urban planning practice (Breuste, 2010; Barthel \& Isendahl, 2013; Barthel, Parker, \& Ernstson, 2015). While research on green infrastructures acknowledges the role of urban gardens for long-term food security in cities (Barthel \& Isendahl, 2013), the role of garden dwellings in allotments has to date been neglected. The aim of our research is to uncover both the tradition and evolution of garden dwellings in Austrian and German allotment garden traditions as well as the resilience capacity of this specific allotment feature. Contrary to UK allotment tradition, where overnight stays on garden lots are not permitted, both seasonal and permanent dwelling are a constituent part of continental European allotment tradition (Crouch \& Ward, 1997; Weirich, 2007). This paper attempts to show that 
clear rules concerning allotment dwellings can significantly contribute to preserving allotment gardens in central urban areas as well as safeguarding ecosystem service provision in allotments.

Even though allotments and allotment gardening are regulated by law, users' sustained informal practices, tolerated by associations, or even endorsed as in Vienna by the municipality, also influence and shape these urban territories (Weirich, 2007; Oldengott, 2007). A comparison of historic developments and the legal framework shows that in most cases legal regulation took place after the fact (Katsch \& Walz, 2001). The progression of land appropriation and individual use in the framework of collective organisation (allotment associations) resembles other suburban processes in the early twentieth century in large European cities (Kuhn, 2006; Hoffmann, 1987). It is allotment gardening's position at the interface between the informal und the regulated that makes it so exceptional. Research on sustainable and green features of urban allotment gardens does not take account of the role of historical traditions. In many European countries, allotment gardening is still in the tradition of largely informal urban practices. Only in Austria, Germany, the UK, and Slovakia, are allotment gardens legally protected. In these countries, allotment federations and associations have successfully fought for legal rent control and the stable and secure use of municipally owned land (Weirich, 2007). Elke Krasny calls this ongoing process "hands-on urbanism," a "radical strategy which shaped urban development from the mid-nineteenth century to today's neoliberal city" (Krasny \& Architekturzentrum Wien, 2012). Negotiations between municipal authorities and allotment associations can thus be seen as effective models for participation in urban planning. This tradition is very likely to continue. In order to understand and strategically include allotment garden use in formal urban planning procedures, knowledge is required of historical conditions and continuing traditions. We aim to uncover the specifics of this process by comparing historical allotment practice with the evolution of the regulatory framework.

\section{Some definitions and characteristics of allotment gardening}

Micheline Nilsen, who has compiled a comprehensive history of allotment gardening in England, France and Germany, defines allotment gardens as follows: "Allotments are a very specific type of garden: usually of small size, not attached to a dwelling, they are cultivated by their tenant and family for individual consumption of produce they yield (Nilsen, 2014, p. 1)."

In the German and Austrian allotment tradition, "Laube" is usually a solidly built small house of massive or wooden construction and in most cases with a pitched roof (Thiel, 2007). Initially, "Lauben" were built by allotment holders on their own, often with the help of fellow gardeners. As shown in Table 1, minimalist garden dwellings range from small $\left(16 \mathrm{~m}^{2}\right)$ to medium (24-35 $\left.\mathrm{m}^{2}\right)$ and large $\left(50 \mathrm{~m}^{2}\right.$ in Vienna, in 1959 and after 1992). These small houses consist of one or two rooms, which enable temporary use during the summer. However small, these minimalist dwellings are very often equipped with all contemporary amenities for comfortable living: a small bathroom, a kitchen facility and a multifunctional living room, which is used as sleeping quarters at night (Thiel, 2007) (Crouch \& Ward, 1997). The use of "Lauben" as a permanent residence continues but is also currently called into question (Thiel, 2007). Garden lot size ranges from small $(100250 \mathrm{~m} 2)$ to medium $\left(250-500 \mathrm{~m}^{2}\right)$ and large $\left(500-1000 \mathrm{~m}^{2}\right)$. Lots are arranged along a network of pedestrian pathways. The surface of pathways is not sealed. According to the German Federal Allotment Garden Act (Bundeskleingartengesetz, 1983) individual garden lots within an estate must be used for vegetable and fruit growing ("kleingärtnerische Nutzung"), otherwise the character of allotment garden use is lost. However, on-site visits and publications by the allotment gardening federation show conflicting and informal practices in different allotment 
associations. In Austria, kitchen gardens were mostly transformed into representative gardens for leisure (Breuste, 2010). In both countries, small trees, predominantly fruit trees, can be found in allotments. Conifers are common, but at least in Germany, highly contested (Thiel, 2007).

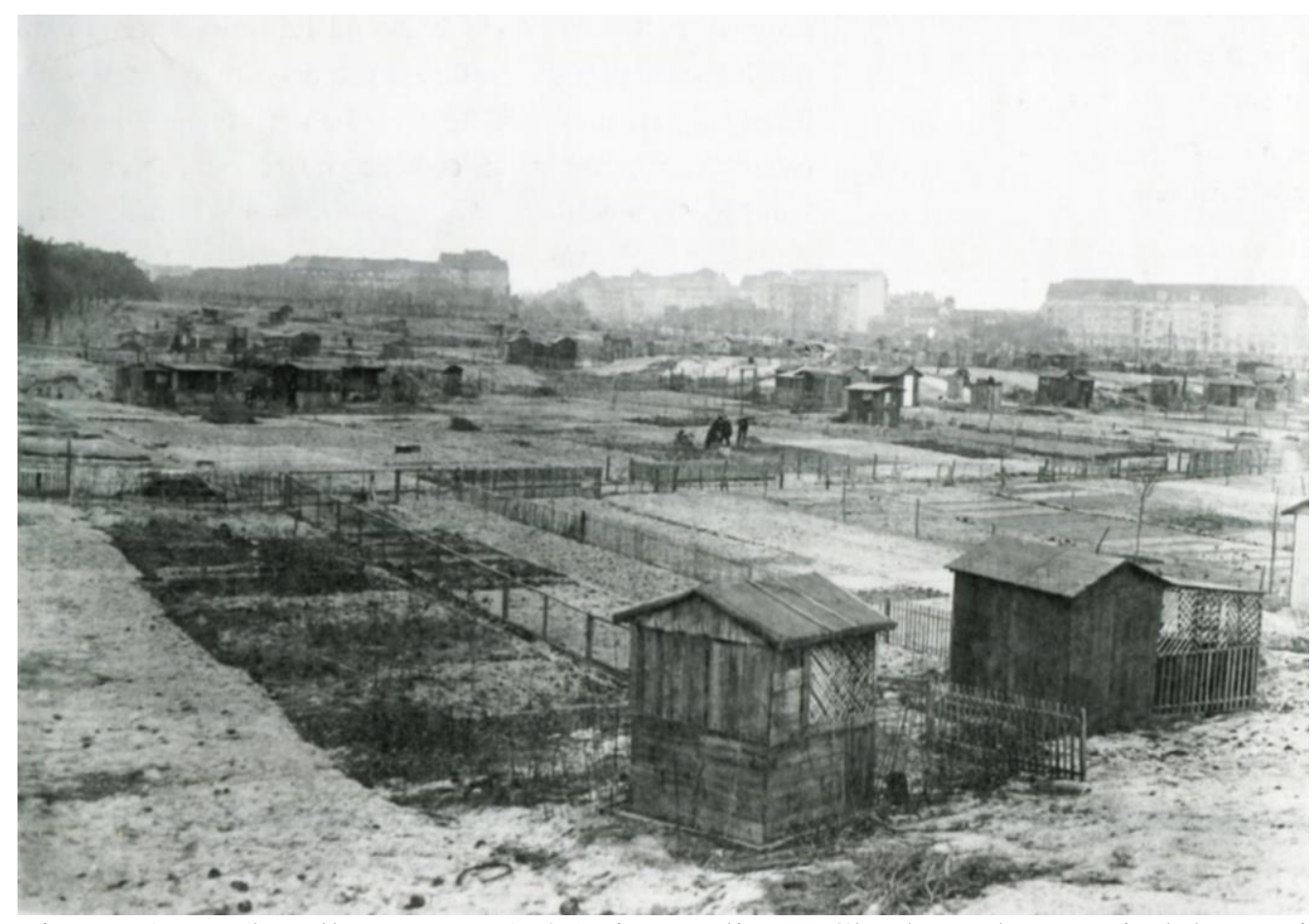

Figure 1: Early allotments (1905) in Berlin - Charlottenburg-Witzleben with no trees or schrubbery due to precarious use; Photograph by Willy Römer (source: Warnecke, 2001).

\section{Research on allotment gardening}

Most research on allotment gardening focuses solely on the historical development. Hartwig Stein has examined the cultural history of German allotment gardening until the end of the Second World War, focusing on Hamburg (Stein, 2000). Micheline Nilsen has compiled a comprehensive overview of studies on the allotment garden movement between 1870 and 1919 in England, France and Germany (Nilsen, 2014). One particularly interesting study on private urban fringe settlements in Berlin was conducted in 1933 by the German Archive for Settlement (Deutsches Archiv für Siedlungswesen 1933). It describes the commercial process of subdividing lots into buildings sites but also informal settlers' building practices, as well as the composition of buildings (Deutsches Archiv für Siedlungswesen, 1933). In Germany, current research and publications on allotment gardening are largely concerned with problem solving (BMVBS/BBR, 2008; BMBVS, 2013). There is also an EUwide project "Urban Allotment Gardens" under the European Union COST programme in which partners from several European countries examine national case studies and different gardening cultures but also study the role and impact of allotment gardens in the urban green network such as habitat connection, ecosystem service provision, biodiversity, the water cycle, micro-climate regulation (Urban Allotment Gardens, 2012). The findings of this research network will be published in 2016.

\section{Classification of allotment gardens}

In order to assess the ecologic qualities of allotment garden zones as green infrastructure and according to the criteria of ecosystem services, we analysed existing research on 
greenspace monitoring types developed by the Vienna Municipal Department 22 (Müllner \& Kramer, 2010), urban vegetation structure types (UVST), an approach developed by Mathey et.al. (2011) and Lehmann et al. (2014), and, finally, indicators and proxies for categorizing and valuing ecosystem services as synthesized in 2013 (Gómez-Baggethun \& Barton, 2013).

When compared to multiple functions of ecosystem services, as defined by Bolund and Hunhammer as early as 1999 and now widely recognized, allotment gardens offer at least five of the six ecosystem services listed by these authors. Ecosystem services of allotment gardens include air filtering, microclimatic regulation, noise reduction, rainwater drainage as well as recreational and cultural values. In this primary classification, allotments belong to the category of cultivated land (Bolund \& Hunhammar, 1999). Even though this early analysis does not explicitly list allotment gardens as a distinct category, later publications clearly identify urban allotments as one of the crucial green resources for the provision of urban ecosystem services (Breuste, 2010; Gómez-Baggethun \& Barton, 2013; Speak, Mizgajski, \& Borysiak, 2015).

Research on urban vegetation structure types (UVSTs) has shown that green infrastructures heavily influence microclimatic conditions in densely built-up areas. This approach can be used to closely monitor microclimatic impacts of different UVST at both the city and urban district levels and further investigate ecosystem services (Lehmann et.al. 2014). A similar method of monitoring green space, based on greenspace-structure types and green-area top-types, was developed in Vienna, with the aim of monitoring changes in vegetation and soil-sealing and to provide empirical basis for strategic planning decisions (Müllner \& Kramer, 2010).

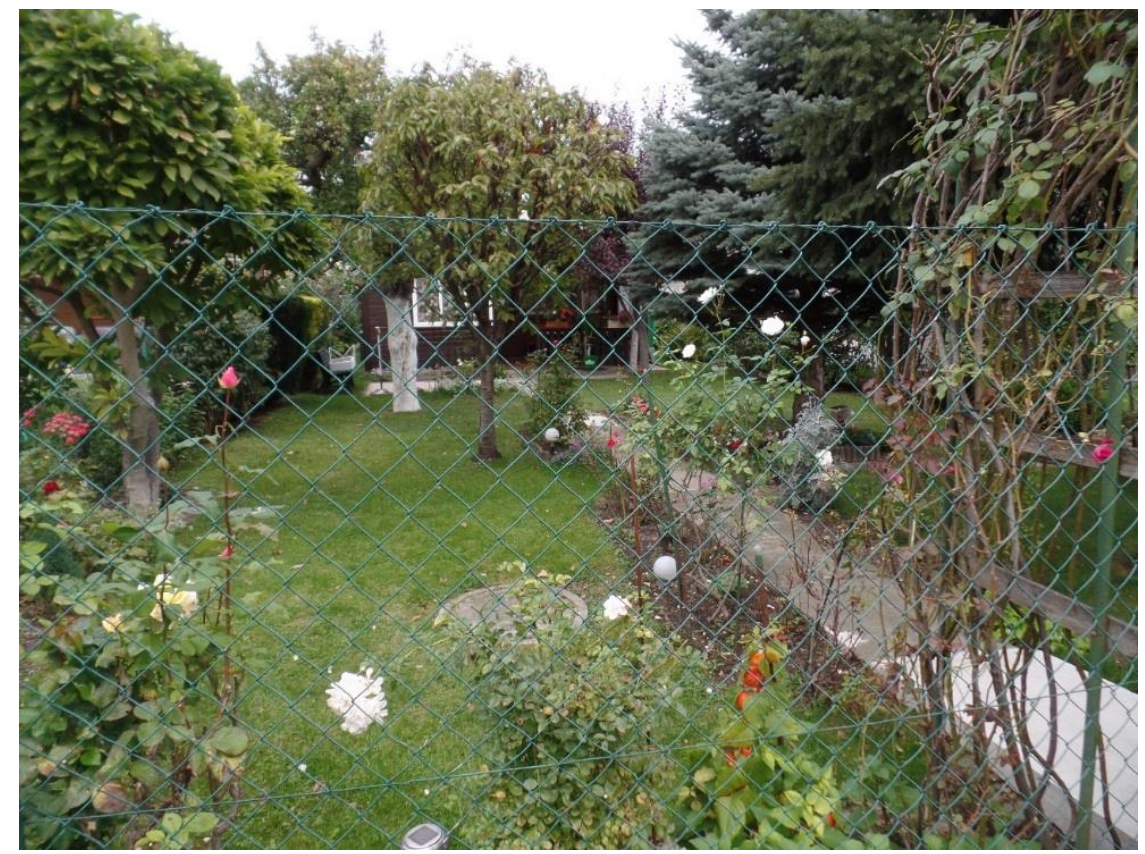

Figure 2: Predominantly flower garden vegetation with small trees in Viennese allotments in 2015 (photo: Maja Lorbek).

The greenspace monitoring type approach developed in Vienna offers a two-level classification method. Each urban element is categorized according to green-areastructure type (GA-ST) ("Grünflächen-Strukturtyp"), which defines each element according to its use within the urban territory and then according to the so called "top type" (TT) classification, which describes vegetation and the potential of the given type as a nature-oriented habitat for plants, animals and people. In Vienna, 58 top types were identified, which were then reduced for manageability reasons to 13 higher level top types (MA 22 Wien, 2008). 
Lehmann et al. have examined urban greenery in Dresden using a digital urban biotope map of the city. In this study, there are 13 main categories of urban vegetation structure, based on the use of the particular area and 57 urban vegetation structure types (UVSTs) (Mathey, 2011) (Lehmann et al., 2014). Table 1 shows the classification of allotment gardens according to the above methods.

Table 2: Classification of allotment by urban vegetation type, according to MA 22 Wien (2008) and Lehmann et al. (2014)

\begin{tabular}{lllll}
\hline Greenspacemonitoring Wien & UVST approach Lehman et. al. & \\
\hline GA-ST & Top type & Main category & UVST & \\
8. & 21. & 1. & 1.6 & \\
"Kleingarten" & Allotment & Residential sites, mixed-use & Built-up & land \\
(allotment) & Higher level type: & sites as well as industrial, with trees & and \\
& Scattered & commercial and specialized & extensive & \\
& development & sites & shrubbery & \\
\hline
\end{tabular}

Source: MA 22 Wien (2008) and Lehmann et. al. (2014)

The city of Vienna regularly monitors changes in green spaces in Vienna. Changes between 2000 and 2005 were evaluated in 2008. The report on greenspace monitoring clearly identifies an increase of sealed surfaces in Vienna by approximately 350 ha. Detached housing and allotment areas with year-round dwellings are among the most rapidly changing urban areas. Construction activities in these two areas resulted in a high increase of sealed surfaces. The decrease of green space was highest among the types of space compared. Viennese monitoring clearly indicates that increasing built-up space in allotment gardens, as as shown by the table for the state of Vienna, significantly decreases the area of green space in allotments (MA 22 Wien, 2008). Further research on eco-system services in which the specifics of allotments and their historical traditions are taken into account, is needed.

\section{Methods}

Our method is based on the evaluation and re-interpretation of historical traditions and on comparative analysis of current developments (planning policy in Vienna, Austria in comparison to German policy). Traditionally, planning history (urban planning, landscape planning, and architecture) gathers historical facts in order to categorise and describe dominant developments but also to define canonical objects. We use historical analysis to identify the crucial conceptual frames behind artefacts and "second nature." The gradual development and crucial changes in legal provisions and urban planning regulations are similarly compared to the actual practices of users. Re-emergent informal practices, which defy regulation and laws, are then identified as fundamental and constitutive features of specific urban formations and practices. This approach relies on discourse analysis and, furthermore, is based on on-site visits to allotment garden associations in Vienna, Berlin, and Dresden. We used historical photographs and our own documentation of garden vegetation and garden dwellings to identify re-emergent features and practices. This additional material allowed us to broaden the knowledge base on institutional frameworks. We proceeded as follows: After categorizing the chief characteristics of traditional allotment gardening, we compared the gradual evolution of legal and zoning regulations in Austria and Germany.

\section{Results}

\section{Historic development of allotment gardens}

In the mid-nineteenth century, some German cities started to provide gardens for the poor. Based on the idea of self-help and self-sufficiency, these rental garden lots were philanthropic 
efforts (Nilsen, 2014). The goal was to allow the poor to grow garden produce for their own needs. These early urban green space infrastructures quickly turned into built up areas due to the rapid extension of the city limits and land speculation (Stein, 2000). Later on, however, the idea to provide garden lots within the city resurfaced, both in for the pursuit of healthy living and also as an informal solution to urgent food and housing shortages following the two world wars, but also during the time of hyperinflation and financial crisis in the 1920s. The general system used in Berlin, Bremen, Hamburg, and Nürnberg that allowed private landowners and municipalities alike to lease out vacant building sites, enabled temporary garden lots to be established (Stein, 2000). During the early stages, allotment land use was transitory, precarious and often only partly legal (Migge, 1913) (Warnecke, 2001) (Kuhn, 2006).

Since 1919, the official term for allotment gardens in German has been "Kleingärten." Another, frequently used term is Schrebergärten. This expression goes back to the establishment of the allotment garden lot association in 1865 by Dr. Ernst Innozenz Hauschild in Leipzig. The association was named after a physician called Dr. Schreber, who promoted child education on the basis of healthy outdoor activities and gardening. The original garden plots were intended for children, but they failed to capture their interest and so the families took over the gardens (Nilsen, 2014). Even though Dr. Schreber is incorrectly seen as the inventor of German Kleingärten, the collective form of the Leipzig association nevertheless later became one of the main characteristics of allotment gardening in German-speaking countries. In 1909, Franz Dinghofer brought the Schrebergarten idea to Vienna. The administration and politicians later recognized the importance of allotment gardening in core urban areas, precisely because of their capacity to absorb housing needs and ensure food provision in times of crisis, but also due to collective forms of allotment garden holders' organisations, which demanded more permanent and longer rental forms (Migge, 1925; Katsch \& Walz, 2001). Due to increasing industrialisation, demographic growth and overcrowded housing in fast growing cities, numerous movements evolved with the objective to improve living conditions for the poor and to promote alternative lifestyles: the land-reform movement, the Garden City movement, the housing settlement (Siedlung) movement, the Life Reform movement as well as the allotment garden movement (Nilsen, 2014).

Settlements of modest dwellings on city fringes, which emerged in the late 19th century, for instance in Berlin, are called Laubenkolonien, which literally means colonies of garden sheds (Nilsen, 2014). A research report from 1930s on the topic of private settlement on the periphery of Berlin categorized these settlements as "private Stadtrandsiedlungen" (private urban fringe settlements). In these settlements, the transition from makeshift and temporary to firm and legal is a longer, gradual process (Deutsches Archiv für Siedlungswesen, 1933). The origin and establishment of the garden shed as a seasonal dwelling in garden lots in Germanspeaking countries needs further research. Gardeners, who initially built garden sheds for storing tools and garden produce, soon started to use these primitive shelters in times of financial hardship and during periods of severe housing shortages as emergency accommodation, often illegally (Kampffmeyer, 1926; Stein, 2000). As gardening took place during leisure time, garden huts thus also started to serve as seasonal summer homes. During the expansion phase of industrial cities, a temporary lease system for designated building sites emerged. This commercial model was based on the principle of the general rental system (Generalpachtsystem) (Nilsen, 2014). Before World War I, an official welfare institution started to promote allotment gardening as an economic and educational measure for large families, the sick and the needy (Nilsen, 2014).

At the beginning of the twentieth century, allotment gardening gained popularity, because of its capacity to provide both shelter and food during hard times, but also due to the support of social democratic governments in cities like Vienna, Berlin and Frankfurt am Main. During 
the First World War and the early 1920s (hyperinflation, refugees), affordable accommodation in cities became even more scarce. There was also a severe food shortage. Gardening on the fringes of large cities, such as Berlin and Vienna, proliferated. For the lower classes, growing their own food - on municipal land, in parks and in Vienna even on cleared sites in surrounding forest areas - became a form of survival. Particularly in times of housing shortages in after-war periods during the twentieth century, allotment gardens served as emergency accommodation (Kampffmeyer, 1926; Hochhäusl, 2013) .

Allotment gardening in Austria and Germany today is firmly established (Weirich, 2007). Large units of land in central city areas have been preserved. According to the German Leisure Garden federation (BDG) there are approximately 1 million garden lots in Germany, with 5 million users, organised in 14.000 allotment associations (BDG, 2015). In Austria, there are approximately 39.000 allotments organised in 384 associations. The majority of Austrian garden lots are located in Vienna, with 26.831 garden lots and 247 associations (Zentralverband der Kleingärtner, 2015).

Allotment garden regulations in Austria and Germany prescribe fruit and vegetable gardening as the main feature of this zoning category (see table 1). Some authors, and the ongoing discussion in garden allotment organisations, show that the utilisation of gardens is changing. These green areas, once predominantly used to produce homegrown food and keep small animals, are now increasingly serving as gardens for recreational purposes with ornamental lawns and pools (Breuste, 2010). Our own on-site visits show that some allotment gardens in Vienna, Dresden, and Berlin are also equipped with common facilities, such as clubhouses, small restaurants and children's playgrounds. However, the share of built up area and of sealed surfaces remains limited in comparison to traditional detached housing areas on city fringes, foremost because of non-sealed surface and limited dimensions of pedestrian pathways. Similarly, the complexity of technical infrastructures is also limited, as electricity, water supply and sewage are not provided in all allotment gardens. All this applies to Viennese allotments prior to 1992. The unique transformation of allotment gardens in Vienna after 1992 is described and critically discussed in the following section.

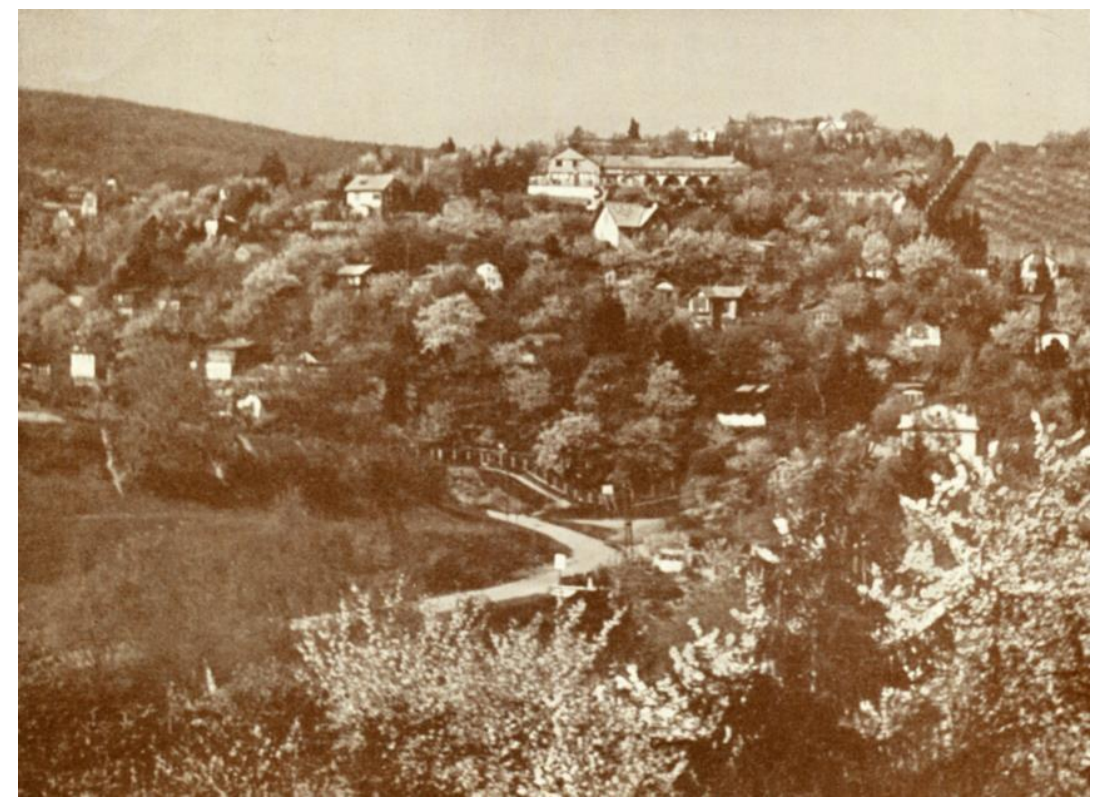

Figure 3: Allotments (1939) in Vienna - Rosental. From the very beginning, buildings in Viennese allotments were relatively big (source: Siedlungs- und Kleingartenamt der Stadt Wien, 1939). 


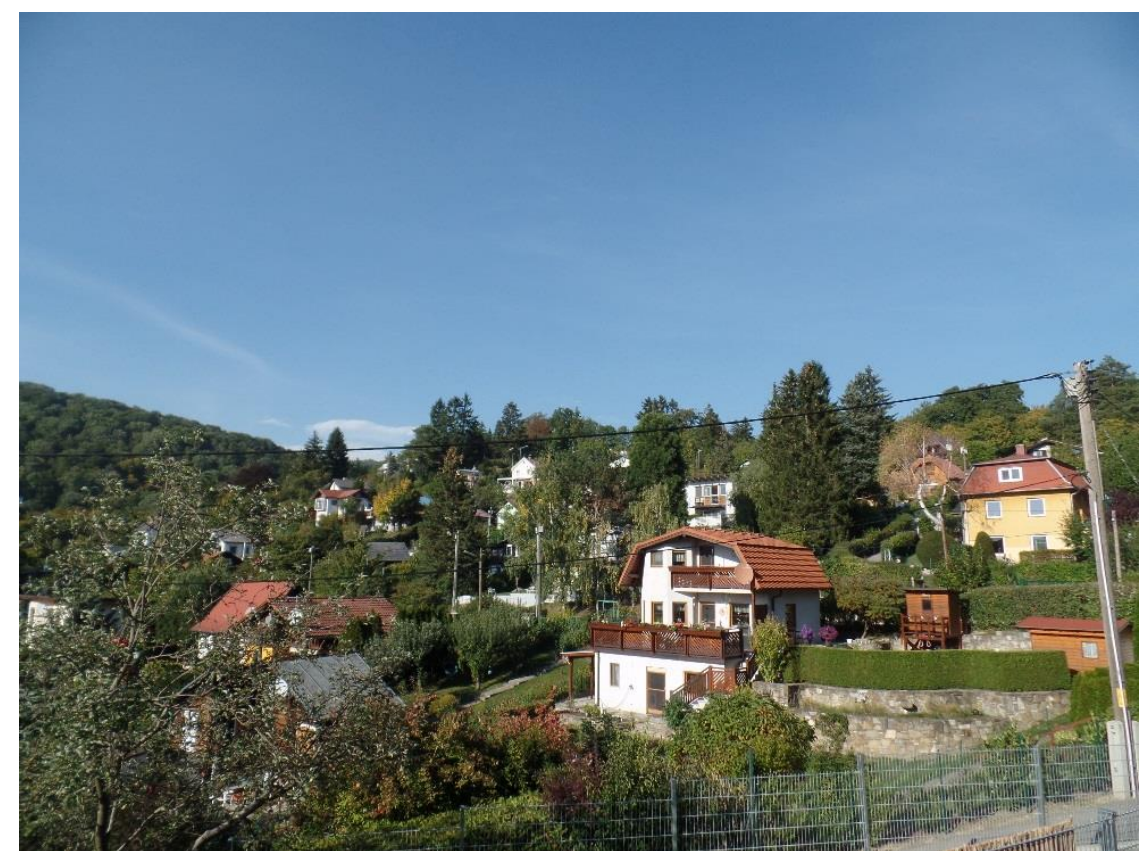

Figure 4: Allotments in Vienna - Rosental in 2015 (photo: Maja Lorbek).

\section{Early twentieth Century legislative framework}

In Austria, the first ordinance regulating allotment gardening and the rental system was passed in 1917, mainly to regulate the general rental system in wartime. Immediately after the war, in 1919, the Allotment and Small Holdings Ordinance 1919 was adopted under the German Weimar republic (Nilsen, 2014). This ordinance protected allotment holders against rent speculation, which was common in the pre-war era. The ordinance did not include any regulation of the size and use of garden huts ("Lauben".) Allotment use, nevertheless remained precarious, particularly in cities suffering from a housing shortage, such as Berlin (Hobbs, 2012). In 1935, however, the 1919 ordinance was amended and regulations concerning "Lauben" for permanent dwelling were explicitly mentioned (Amendment to Allotment and Small Holdings Ordinance 1935). According to Paragraph 2 of this law, the owner of an allotment site (landlord) was entitled to receive rent for a garden hut used as a permanent dwelling. Paragraph 3, Section (3) regulated eviction and termination protection for garden huts used as permanent dwellings before March 31st 1935 and where residents could not find other accommodation under acceptable conditions. The dwellings established prior to this date were thus legalized - after the fact.

Similarly, the state of Vienna adopted an ordinance on allotment gardens in 1936 (Viennese Allotment Garden Ordinance 1936), which regulated the establishment of both allotment garden estates as well as buildings on these sites. This ordinance also contained a description of an allotment garden, defined as follows: "Allotments are small sized plots of land used as gardens in a non-commercial manner" (Viennese Allotment Garden Ordinance 1935). Furthermore, the ordinance regulated the construction of buildings on garden plots. At this point, in Vienna, built constructions are already recognized as inherent elements of allotment gardens. This specific tolerance for dwelling construction applies only to the state of Vienna. Other Austrian states each have their own specific regulations and laws for allotments. Their policy is very similar to German strategy, which tolerates informal permanent dwellings on garden lots to a certain degree, but in no way permanently legalizes this practice. According to $\S 9$ "Permitted buildings" ("Zulässige Bauten") section (1) of the Viennese allotment ordinance of 1935, the erection of summer huts suitable for seasonal dwellings during the summer is permitted. The maximum built up area allowed is $50 \mathrm{~m}^{2}$ and the built area is restricted to a maximum of $10 \%$ of the total plot surface. Residence is limited 
to seasonal use from April 15th until October 15th of the given year. Paragraph 5, section (1) regulates plot size, which should, as a general rule, be at least $500 \mathrm{~m}^{2}$. The 1935 ordinance also contains several rules on construction materials, height, roofs, as well as the requirement to equip each summer hut with a toilet connected to dwelling areas. Both attic floors suitable for living, as well as limited cellars are permitted. Viennese regulations from 1935 are very liberal, allowing the construction of relatively large detached houses, equipped with all the necessary basic living amenities. These garden dwellings are the same size as the small single-family homes ("Kleinhaus") constructed during this era.

The foundations for the later conversion of seasonal garden dwellings into permanent detached houses in Vienna were already laid in 1936. In 1992, allotment gardens with summer cabins under the 1936 ordinance were divided in two categories: traditional "Kleingarten" settlements with seasonal use and a new zoning category for year-round living.

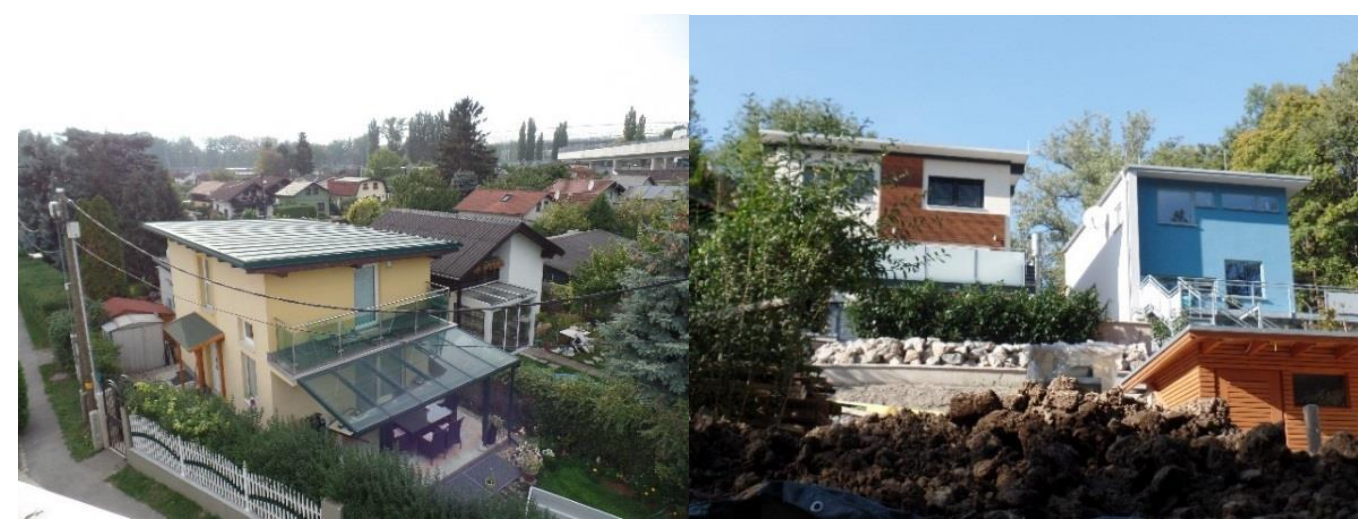

Figure 5, 6: Allotments in Vienna - Allotment association "Grünland" and Rosental in 2015, domination of dwelling use (photo: Maja Lorbek).

\section{Legislation in Austria from 1939 to 1992}

Between 1939 and 1959, following the forced incorporation of Austria into Nazi Germany, the 1919 German Allotment and Small Holdings Ordinance came into force there. In 1958, after Austria regained its independence in 1955, the German law was substituted by the Austrian Allotment Garden Act of 1958. The newly adopted federal act mainly regulated the rent system in allotments with no rules on the size of plots or restrictions on dwellings. Rules on buildings and plot size were included in the building regulations at the state level. In 1959, a new Viennese state act on the establishment of allotments and their legal use was adopted (Viennese Allotment Garden Act 1959). The maximum built-up area for allotment buildings was reduced to $25 \mathrm{~m}^{2}$ and a new category, the "Laube" was introduced, meaning a garden building for non-dwelling purposes with a maximum of $16 \mathrm{~m}^{2}$ built-up area. Regulations called for garden lot sizes between 250 and $350 \mathrm{~m}^{2}$. This act also presented a new definition of allotment gardening in the state of Vienna. In addition to non-commercial garden use, leisure was now declared a purpose of allotments.

In 1978 the state of Vienna adopted a new Allotment Garden Act (Viennese Allotment Garden Law 1978). This time, the promotion of health was added to the goals of allotment gardening. The term "Kleingartenhaus" (Allotment garten dwelling) was introduced, meaning a small building consisting of at least one room, and not intended for use as a permanent residence. Despite this restriction, not only the maximum allowed size of garden lots was increased, but also the maximum built-up area for buildings was increased from 25 to $35 \mathrm{~m}^{2}$ (Viennese Allotment Garden Act, 1978, See also Table 1). In 1992, the Viennese Allotment Act was amended to extend the use of allotment gardens to housing. Two new zoning categories were also introduced: green - leisure areas - for year-round living and green- 
leisure areas for allotment gardening. This amendment regulated technical infrastuctures for permanent dwellings on garden lots (Amendment to Viennese Allotment Garden Act, 1992).

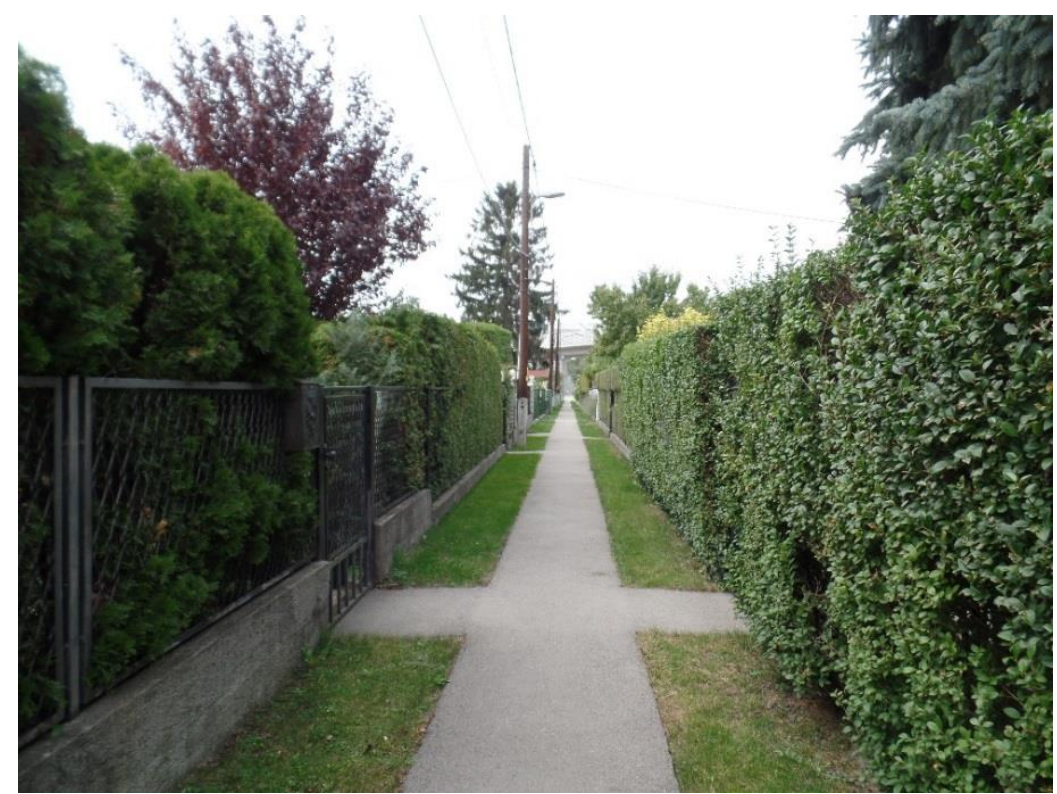

Figure 7: Allotments in Vienna - Allotment association "Grünland" in 2015, increase of sealed surface (photo: Maja Lorbek).

\section{German Legislation from the Weimar Republic to 1983}

In the Federal Republic of Germany after the Second World War, the 1919 Allotment and Small Holdings Ordinance as amended in 1935 and 1940 was still in force. Only in 1983 as the German Federal Act on Allotment Gardens was adopted (Bundekleingartengesetz, 1983). Paragraph 1 (1) defines allotments as gardens for the non-commercial production of horticultural products for private use. In order to be recognised as a garden allotment, a garden site also must be a part of larger estate composed of several gardens. Paragraph 3 limits the size of garden lots to $400 \mathrm{~m}^{2}$, and the built-area of a "Gartenlaube" must not exceed $24 \mathrm{~m}^{2}$, including the area of covered terrace. Garden shed facilities should exclude permanent residence on the garden lot. However, existing buildings larger than $24 \mathrm{~m}^{2}$ and existing legal permanent residences remain unaffected. Unlike the Viennese legislation, the establishment of permanent residence in German allotment estates was officially never - at any time from 1919 to the present day - explicitly promoted in German allotments. However, in periods of crisis, the authorities made provisional exceptions, for instance in 1946 in Berlin . The Guidelines for Building Inhabitable Garden Buildings (Germ. „Richtlinien für die Errichtung bewohnbarer Lauben") conceded the right to reside in garden buildings with a maximum built-up area of $30 \mathrm{~m}^{2}$ for a limited period of time (Richtlinie für die Errichtung bewohnbarer Lauben, 1946). Nevertheless, an analysis of the current discourse on the future development of allotment gardening has shown that there is considerable legal uncertainty, due to vague definitions in the law itself, but also due to a long period of provisional legal regulation (1949 - 1983) and differing approaches of local allotment associations to informal practices with respect to garden dwellings (Thiel, 2007).

Table 1 provides an overview of the evolution of the law pertaining to allotment gardens concerning vegetation, lot size, buildings, and residence. 
Table 1: Overview of allotment legislation in the Federal Republic of Germany, the state of Vienna: regulation of vegetation, garden lot size, size of buildings on garden lots and rules concerning residency (laws of German Democratic Republic are not included).

\begin{tabular}{|c|c|c|c|c|c|c|}
\hline $\begin{array}{l}\text { Name of } \\
\text { regulation }\end{array}$ & Territory & Year & Vegetation & $\begin{array}{l}\text { Size of garden } \\
\text { lot }\end{array}$ & $\begin{array}{l}\text { Regulations for } \\
\text { buildings on lots }\end{array}$ & Residence \\
\hline $\begin{array}{l}\text { Allotment } \\
\text { and Small } \\
\text { Holdings } \\
\text { Ordinance }\end{array}$ & $\begin{array}{l}\text { Germany, } \\
\text { (in } \\
\text { Austria } \\
\text { between } \\
1939 \text { and } \\
1958 \text { ) }\end{array}$ & $\begin{array}{l}1919, \\
\text { amendments } \\
\text { in } 1935 \text { and } \\
1940\end{array}$ & $\begin{array}{l}\text { Horticultural } \\
\text { use, non- } \\
\text { commercial }\end{array}$ & $\begin{array}{l}\text { Not regulated, } \\
1919 \\
\text { recommendation } \\
\text { by Reich's } \\
\text { Economics } \\
\text { Minister to limit } \\
\text { the size of lots to } \\
625 \mathrm{~m}^{2} \\
\text { (Warnecke, 2001) }\end{array}$ & No regulation & No regulation \\
\hline $\begin{array}{l}\text { Viennese } \\
\text { Allotment } \\
\text { Garden } \\
\text { Ordinance }\end{array}$ & $\begin{array}{l}\text { State of } \\
\text { Vienna }\end{array}$ & 1936 & $\begin{array}{l}\text { Gardening, } \\
\text { garden use }\end{array}$ & At least $500 \mathrm{~m}^{2}$ & $\begin{array}{l}\text { Summer huts } \\
\text { should not exceed } \\
10 \% \text { of total } \\
\text { garden plot area, } \\
\text { the built-up area } \\
\text { limited to } 50 \mathrm{~m}^{2} \text {, } \\
\text { maximum height } \\
\text { roof ridge } 6,5 \mathrm{~m} \text {. }\end{array}$ & $\begin{array}{l}\text { Seasonal } \\
\text { residence } \\
\text { permitted from } \\
\text { April } 15^{\text {th }} \text { until } \\
\text { October } 15^{\text {th }} \\
\text { each year }\end{array}$ \\
\hline $\begin{array}{l}\text { Federal } \\
\text { Allotment } \\
\text { Garden Law }\end{array}$ & Austria & 1958 & $\begin{array}{l}\text { Non- } \\
\text { commercial use } \\
\text { or leisure }\end{array}$ & $\begin{array}{l}\text { From } 120 \mathrm{~m}^{2} \text { to } \\
650 \mathrm{~m}^{2}\end{array}$ & No regulation & No regulation \\
\hline $\begin{array}{l}\text { Viennese } \\
\text { Allotment } \\
\text { Garden Act }\end{array}$ & $\begin{array}{l}\text { State of } \\
\text { Vienna }\end{array}$ & 1959 & $\begin{array}{l}\text { Non- } \\
\text { commercial } \\
\text { gardening, no } \\
\text { walnut trees }\end{array}$ & $\begin{array}{l}\text { Garden lots must } \\
\text { be located in } \\
\text { "green area- } \\
\text { allotment garden } \\
\text { zone" } \\
\text { Size: from } 250- \\
350 \mathrm{~m}^{2} \text {, exception } \\
\text { up to } 650 \mathrm{~m}^{2}\end{array}$ & $\begin{array}{l}\text { Two types: summer } \\
\text { hut } \\
\text { ("Sommerhütte") } \\
\text { up to } 25 \mathrm{~m}^{2} \text { built-up } \\
\text { area; } \\
\text { Garden huts } \\
\text { ("Laube") up to } 16 \\
\text { m² built-up area, } \\
\text { toilets required and } \\
\text { sinkholes are } \\
\text { allowed }\end{array}$ & No regulation \\
\hline $\begin{array}{l}\text { Viennese } \\
\text { Allotment } \\
\text { Garden Law }\end{array}$ & $\begin{array}{l}\text { State of } \\
\text { Vienna }\end{array}$ & 1979 & $\begin{array}{l}\text { Horticultural } \\
\text { use, non- } \\
\text { commercial } \\
\text { gardening, } \\
\text { designated for } \\
\text { leisure and } \\
\text { health purposes }\end{array}$ & $\begin{array}{l}250 \mathrm{~m}^{2} \text { to } 400 \mathrm{~m}^{2} \\
\text { Minimum size } \\
120 \mathrm{~m}^{2} \\
\text { Maximum size } \\
650 \mathrm{~m}^{2}\end{array}$ & $\begin{array}{l}\text { "Kleingartenhaus" } \\
\text { up to } 35 \mathrm{~m}^{2} \text { built-up } \\
\text { area, maximum } 15 \\
\% \text { of total lot area, } \\
\text { several regulations } \\
\text { concerning the } \\
\text { construction }\end{array}$ & $\begin{array}{l}\text { Buildings } \\
\text { generally } \\
\text { designated for } \\
\text { seasonal use }\end{array}$ \\
\hline $\begin{array}{l}\text { Federal } \\
\text { Allotment } \\
\text { Garden Act }\end{array}$ & Germany & 1983 & $\begin{array}{l}\text { Horticultural } \\
\text { use, garden } \\
\text { produce for } \\
\text { own needs, } \\
\text { consideration of } \\
\text { environmental } \\
\text { protection, } \\
\text { nature and } \\
\text { landscape } \\
\text { conservation }\end{array}$ & $\begin{array}{l}400 \mathrm{~m}^{2} \text { maximum } \\
\text { size }\end{array}$ & $\begin{array}{l}\text { "Gartenlaube" up to } \\
24 \mathrm{~m}^{2} \text { max. built-up } \\
\text { area including } \\
\text { covered terrace }\end{array}$ & $\begin{array}{l}\text { Buildings and } \\
\text { infrastructures } \\
\text { not suitable for } \\
\text { year-long } \\
\text { living }\end{array}$ \\
\hline $\begin{array}{l}\text { Amendment } \\
\text { to Viennese } \\
\text { Garden } \\
\text { Allotment } \\
\text { Law }\end{array}$ & $\begin{array}{l}\text { State of } \\
\text { Vienne }\end{array}$ & 1992 & $\begin{array}{l}\text { Introduction of } \\
\text { housing }\end{array}$ & $\begin{array}{l}\text { Maximum size } \\
\text { can exceed } 650 \\
\mathrm{~m}^{2}\end{array}$ & $\begin{array}{l}\text { Two categories: } \\
\text { seasonal allotment } \\
\text { garden dwelling up } \\
\text { to } 35 \mathrm{~m}^{2} \text { built-up } \\
\text { area, } \\
\text { year-round } \\
\text { allotment garden } \\
\text { dwelling up to } 50 \\
\mathrm{~m}^{2} \text { built-up area }\end{array}$ & $\begin{array}{l}\text { Two categories } \\
\text { for dwellings } \\
\text { and zoning, } \\
\text { seasonal and } \\
\text { year-round }\end{array}$ \\
\hline
\end{tabular}




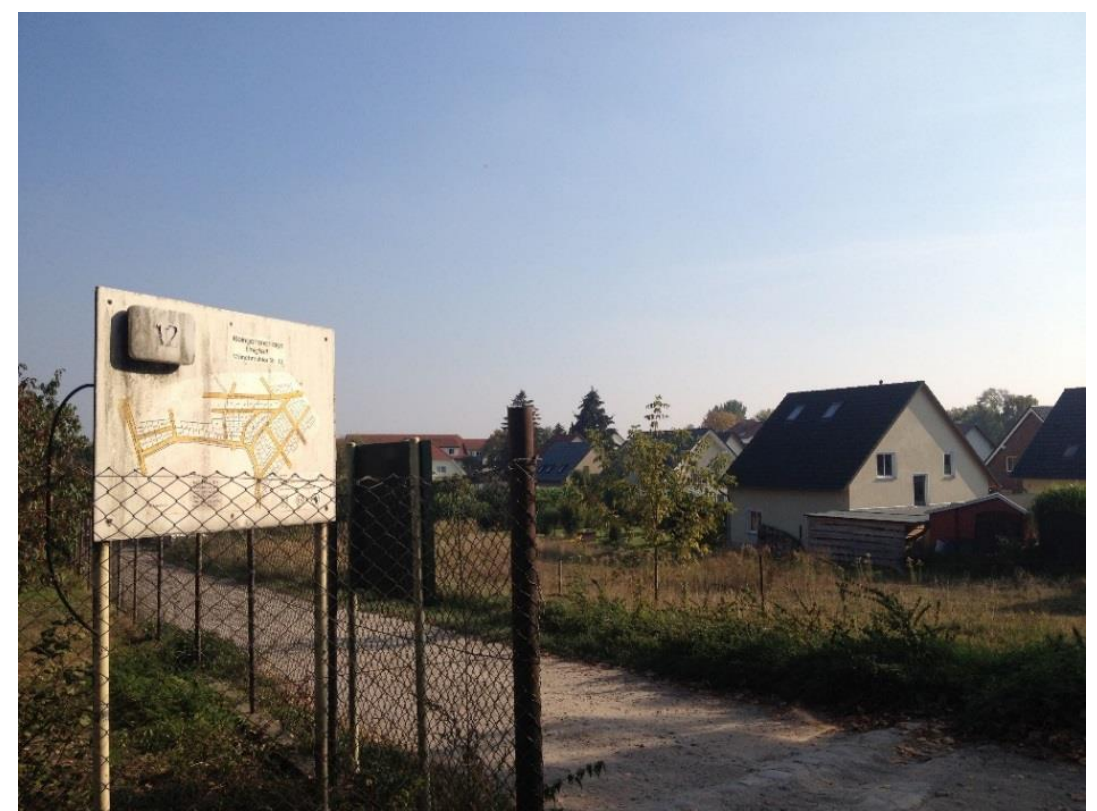

Figure 8: Allotments in Berlin - Intertwined settlements and allotment estates in Berlin Pankow 2015 (photo: Milena Martinsen).

\section{Discussion of legislative framework \\ Regulation and zoning as retroactive processes}

Legal and zoning regulations for this specific form of urban land use were established a posteriori to the established practice of allotment associations and builders cooperatives. Today, the majority of allotment estates are located on municipally owned land. Larger estates are leased to allotment associations on the basis of a general rental system (Generalpachtsystem) (Nilsen, 2014). Associations then sublet plots to their members. This ownership form predominates in most German and Austrian cities. Large plots of unbuilt land thus remained in municipal ownership. Initially, this land use arrangement was initiated as a temporary exploitation of future building sites by municipalities and private landowners. During the late nineteenth century and in the pre-war era in the early twentieth century, leasing allotment gardens was highly precarious. Allotment holders had to surrender their sites as soon as construction started (Stein, 2000). However, a new tradition of wartime allotments, promoted by the authorities, emerged during the First World War. According to Nilsen, allotment land use in large cities such as Berlin and Hamburg rose steadily, and the number of allotment associations increased by $70 \%$. The nature of allotment gardening, rooted in domestic agriculture and education, was transformed into a food-supply agricultural movement (Nilsen, 2014, p. 91). Owing to the war economy, first legal regulations for allotments in Austria and Germany alike were adopted and "some protection against the termination of rental agreements was introduced for the first time (Nilsen, 2014, p. 91).

Early legislation on allotment gardens was limited to regulating the rental system. Over time, legislators also defined the purpose of allotment gardening. Allotments were initially designated for horticultural use and small animal husbandry. Later on, the gardens also served holders for leisure purposes. In Germany, the 1919 Allotment and Small Holdings Ordinance remained the legal framework for allotment gardens until as late as 1983. During this time, the largely informal background of allotment gardening led to disparate practises in different states and local allotment associations. After 1983, the ongoing controversy over desirable and unsolicited uses continues. Both flower gardens without fruit and vegetables and the seasonal use of garden huts and their technical infrastucture are highly controversial. Strict interpretation of the German Allotment Garden Act is not consistent with the actual permissive policy in local assiciations, for instance in North-Rhine Westphalia (Oldengott, 
2007). Legislation in Germany does however, severely limit the built-up area in allotments. Regardless of legal restrictions, existing larger buildings in allotment gardens are often tolerated, depending on the orientation of the allotment association and the general stance of the regional association (Oldengott, 2007). In comparison to Viennese legislation, there is a high degree of legal uncertainty, as allotment dwellings depend on informal rules.

Similarly, in Austria, federal law is fairly vague. Due to the principle of subsidiarity, allotment gardens are regulated differently from one state to another in the country. Viennese allotment law differ from that in force in other Austrian states but Germany. Early on, in the late 1950s, Viennese legislation allowed large garden huts on allotments. Eventually, after a long process of toleration, the Vienna municipality legalised permanent dwelling and yearlong living in allotment gardens in 2002. The careful balance between garden use and minimalist dwellings was abandoned. This lead to some highly problematic developments, particularly an increase of sealed surfaces and the loss of public influence on municipally owned land.

Private ownership of garden dwellings (as opposed to rented garden plots on municipally owned land), as well as highly evolved organisational forms protected allotment gardens in Germany and Austria from conversion into building sites or road infrastructure. According to allotment federations in Austria and Germany, the number of allotment gardens in both countries remains high and allotment gardening continues to be popular (Oldengott, 2007; BDG, 2015; Zentralverband der Kleingärtner, 2015). The lasting popularity of allotment gardening and the existence of large allotment areas, which can be calculated on the basis of the large numbers of members in allotment garden associations and extensive surface of allotment gardens (Zentralverband der Kleingärtner, 2015; BDG, 2015; Weirich, 2007) seem to confirm our hypothesis that legally acknowledged allotment dwellings contribute to preserving allotment practices.

Analysis of the legislation on allotment gardening has shown that federal law in both Austria and Germany remains fairly vague, particularly about vegetation and surface sealing, but also with regard to superordinate goals such as environmental protection, nature and landscape conservation. Assessment of regulations regarding dwellings and seasonal and temporary residence show that dwellings are part of the informal practice in garden lots. Comparison of regulations shows that there are mainly three different approaches for dealing with dwellings. Firstly, fairly strict rules aboutg the size and use of dwellings as in the German Allotment Garden Act 1983. But the ongoing discussion in the Allotment Garden Federation ("Bundesverband Deutscher Gartenfreunde") and our on-site visits suggest that informal practices go beyond what is legally permitted. Secondly, the 1958 Austrian Federal Allotment Garden Act is moderately open with regard to the size and use of allotments. However, there is less controversy over informal practices (Voigt, 2014). Thirdly, there is the approach taken by the state of Vienna, which by and large legalized year-round living in allotment gardens in 1992. This assessment, while preliminary, suggests that there are discrepancies between informal practices and legal regulations, provoking legal uncertainty and controversy. In one case (amendment to Viennese Allotment Garden Act 1992) this conflict was resolved in favour of garden dwellings.

\section{Conclusion}

Analysis of the literature on the history of allotments shows a continued tradition of allotment dwellings in Austria and Germany. Analysis of allotment legislation in these two countries shows different degrees of legality for dwellings during the twentieth century. Both the literature and legal evidence indicate that seasonal as well as permanent allotment dwellings are part of the allotment gardening tradition in these two countries. Further research is needed to better understand the contribution of allotment dwellings to the preservation of 
large allotment areas, thus maintaining ecological qualities and eco-system services provided by this particular practice of urban land use. The development of the legislative framework, which in part remains vague or in contradiction to informal allotment practices, demonstrates that negotiation between allotment gardeners' organisations and the planning authorities is an ongoing process from which important lessons for participative processes in cities can be learned.

\section{References}

Allotment Gardens and Small Holdings Ordinance 1919, law, no.150, Berlin

Amendment to Allotment Gardens and Small Holdings Ordinance 1935, amendment, no. 67,

Berlin

Amendment to Viennese Allotment Garden Law 1992, amendment, no. 31, Wien

Barthel, S., \& Isendahl, C. (2013) Urban gardens, agriculture, and water management: Sources of resilience for long-term food security in cities. Sustainable Urbanisation: A Resilient Future, 86, pp. 224-234. DOI: 10.1016/j.ecolecon.2012.06.018

BDG, B. D. G. (2015) Zahlen und Fakten. Available at: http://www.kleingartenbund.de/bundesverband/portrait/zahlen_und_fakten (accessed 16 Sep. 2015).

BMBVS. (2013) Bewältigung der Leerstandsproblematik in Kleingartenanlagen in strukturschwachen Regionen. Berlin. Available at:

http://www.bbsr.bund.de/nn_23494/BBSR/DE/Veroeffentlichungen/BMVBS/Forschunge n/2013/Heft158.html (accessed on 23 Aug. 2015).

BMVBS/BBR. (2008) Städtebauliche, ökologische und soziale Bedeutung des Kleingartenwesens. Available at: http://www.bbsr.bund.de/cln_016/nn_23494/BBSR/DE/Veroeffentlichungen/BMVBS/Fo rschungen/2008/Heft133.html (accessed 22 Aug.2015).

Bolund, P., \& Hunhammar, S. (1999) Ecosystem services in urban areas. Ecological Economics, 29(2), pp. 293-301. DOI: 10.1016/S0921-8009(99)00013-0

Breuste, J. H. (2010) Allotment Gardens as Part of Urban Green Infrastructure: Actual Trends and Perspectives in Central Europe. In: Müller, N., Werner, P. \& Kelcey, J. G. (eds.), Urban Biodiversity and Design, pp. 463-475. Oxford, UK: Wiley-Blackwell. DOI: 10.1002/9781444318654.ch25

Crouch, D., \& Ward, C. (1997). The allotment: its landscape and culture. Nottingham: Five Leaves.

DeSilvey, C. (2003) Cultivated histories in a Scottish allotment garden. Cultural Geographies, 10(4), pp. 442. DOI: 10.1191/1474474003eu284oa

Federal Allotment Garden Act 1983, no number, federal law, Germany

Federal Allotment Garden Law, 1958, federal law, no. 6, Austria

Gallati, Mischa, \& Schiller, Janine. (2011). Freizeit im Familiengarten : zur regenerativen Funktion der Zürcher Kleingärten seit ihrer Gründung bis in die 1960er-Jahre. http://doi.org/10.5169/seals-177775

Gómez-Baggethun, E., \& Barton, D. N. (2013) Classifying and valuing ecosystem services for urban planning. Sustainable Urbanisation: A Resilient Future, 86, pp. 235-245. DOI: 10.1016/j.ecolecon.2012.08.019

Hobbs, M. (2012). 'Farmers on notice': the threat faced by Weimar Berlin's garden colonies in the face of the city's Neues Bauen housing programme. Urban History, 39(02), pp. 263-284. http://doi.org/10.1017/S0963926812000053

Hochhäusl, S. (2013) From Vienna to Frankfurt Inside Core-House Type 7: A History of Scarcity through the Modern Kitchen. Architectural Histories, 1(1), p. 24. DOI: 10.5334/ah.aq 
Jamnik, B., Smrekar, A. \& Vrščaj, B. (2009) Vrtičkarstvo v Ljubljani. Ljubljana, Založba ZRC.

Kampffmeyer, H. (1926). Siedlung und Kleingarten. Wien, J. Springer.

Katsch, G., \& Walz, J. B. (2001). Kleingärten und Kleingärtner im 19. und 20. Jahrhundert: Bilder und Dokumente. (Bundesverband Deutscher Gartenfreunde, Ed.) (4. Aufl). Leipzig: Bundesverb. Dt. Gartenfreunde.

Federal Allotment Garden Law 1958, no.6, Austrian federal law

Krasny, E., \& Architekturzentrum Wien (eds.) (2012) Hands-On urbanism 1850 - 2012: vom Recht auf Grün. Wien, Turia + Kant.

Kuhn, G. (2006) 'Wildes' Siedeln und 'stille' Suburbanisierung. Von den Wohnlauben zu den privaten Stadtrandsiedlungen. In: Janatková, A.\& Kozinska-Witt, H. (eds.) Wohnen in der Großstadt: 1900 - 1939; Wohnsituation und Modernisierung im europäischen Vergleich, pp. 111-132. Stuttgart, Franz Steiner Verlag.

Lehmann, I., Mathey, J., Rößler, S., Bräuer, A., \& Goldberg, V. (2014) Urban vegetation structure types as a methodological approach for identifying ecosystem services Application to the analysis of micro-climatic effects. Ecological Indicators, 42, pp. 5872. DOI: 10.1016/j.ecolind.2014.02.036

MA 22 Wien. (2008) Gesamtbericht. Projekt Grünraummonitoring Wien. Available at: https://www.wien.gv.at/kontakte/ma22/studien/pdf/monitoring-2005-1.pdf (accessed 6 Sep.2015. ).

Mathey, J. (eds.) (2011) Noch wärmer, noch trockener? Stadtnatur und Freiraumstrukturen im Klimawandel: Abschlussbericht zum F+E-Vorhaben (FKZ 3508821 800) 'Noch wärmer, noch trockener? Stadtnatur und Freiraumstrukturen im Klimawandel'. Bonn, Bad Godesberg, Bundesamt für Naturschutz.

Migge, L. (1913) Die Gartenkultur des 20. Jahrhunderts. Jena, Eugen Diederichs. Available at: http://media.obvsg.at/AC01249971-1001 (accessed 18 Sep. 2015).

Müllner, K., \& Kramer, K. (2010) Wie entwickelt sich der Grünraum in Wien. In: Real Corp (2010) Wien. Available at: http://www.corp.at/archive/CORP2010_133.pdf (accessed 23 Aug. 2015).

Nikolaidou, S. (2014) Emerging forms of Urban Gardening in Geneva. Available at: http://www.urbanallotments.eu/fileadmin/uag/media/STSM/STSMReport_SN.pdf (accessed 18 Sep. 2015).

Nilsen, M. (2014) The working man's green space: allotment gardens in England, France, and Germany, 1870-1919. Charlottesville, University of Virginia Press.

Oldengott, M. (2007) Kleingärten im Ruhrgebiet: Facetten - Trends - Tendenzen u. a. in Essen, Dortmund, Castrop-Rauxel. In: Dokumentation Kongress: 11. Mai 2007 (eds.) Kleingärten mit Zukunft - Lebenswerte Stadt. Dokumentation Kongress: 11. Mai 2007. Hamburg. Available at:

http://www.hamburg.de/contentblob/134998/data/dokumentation-kleingartenkongressdruckversion.pdf (accessed 23 Aug. 2015 ).Segers, \& Van Molle, L. (2014). Workers' Gardens and Urban Agriculture. The Belgian Allotment Movement within a Global Perspective (from the Nineteenth to the Twenty-first Century). Agrargeschichte Und Agrarsoziologie, (Heft 02/2014). Retrieved from https://www.wisonet.de:443/document/ZFAA_893C640AF730D047736C74DB6C6CD636

Schubert, F. (1939) Das Kleingartenwesen in Wien. Wien, Siedlungs- und Kleingartenamt. Speak, A. F., Mizgajski, A., \& Borysiak, J. (2015) Allotment gardens and parks: Provision of ecosystem services with an emphasis on biodiversity. Urban Forestry \& Urban Greening, 14(4), pp. 772-781. DOI: 10.1016/j.ufug.2015.07.007

Spilková, J., \& Vágner, J. (2016). The loss of land devoted to allotment gardening: The context of the contrasting pressures of urban planning, public and private interests in 
Prague, Czechia. Land Use Policy, 52, pp. 232-239.

http://doi.org/10.1016/j.landusepol.2015.12.031

Stein, H. (2000) Inseln im Häusermeer: eine Kulturgeschichte des deutschen

Kleingartenwesens bis zum Ende des Zweiten Weltkriegs, reichsweite Tendenzen und Groß-Hamburger Entwicklung. Frankfurt am Main, Lang.

Thiel, D. (2007) Perspektiven aus Sicht der Verbände. In: Dokumentation Kongress: 11. Mai 2007 (eds.) Kleingärten mit Zukunft - Lebenswerte Stadt. Dokumentation Kongress: 11. Mai 2007. Hamburg. Available at:

http://www.hamburg.de/contentblob/134998/data/dokumentation-kleingartenkongressdruckversion.pdf (accessed 23 Aug. 2015).Urban Allotment Gardens (2012) Urban Allotment Gardens, Objectives and Benefits. Available at:

http://www.urbanallotments.eu/action-in-detail/objectives-and-benefits.html (accessed 18 Aug. 2015).

Viennese Allotment Garden Ordinance 1936, ordinance, no. 36, Wien

Viennese Allotment Garden Law 1959, law, no. 11, Wien

Viennese Allotment Garden Law 1979, law, no. 3, Wien

Voigt, A. (2014). Cultivation, Leisure Time and the Housing Market - An Overview of Urban Allotment Gardens in Austria. In: Urban Allotment Gardens in European Cities. Future, Challenges and Lessons Learned, event report COST Action TU1201, Retrieved from http://www.urbanallotments.eu/fileadmin/uag/media/Lisbon/Lisbon_report_NK8.pdf, accessed on 6 Jan, 2016.

Warnecke, P. (2001) Laube Liebe Hoffnung. Kleingartengeschichte. Berlin, W. Wächter.

Weirich, M. (2007) Kleingärten in Europa: Überblick. In: Kleingärten mit Zukunft Lebenswerte Stadt, Dokumentation Kongress: 11. Mai 2007. Hamburg. Available at: http://www.hamburg.de/contentblob/134998/data/dokumentation-kleingartenkongressdruckversion.pdf (accessed 23 Aug. 2015).

Zentralverband der Kleingärtner (2015) Wir über uns. Available at: http://www.kleingaertner.at/wir.htm (accessed 17 Sep. 2015).

Acknowledgement: This research is part of the the 'Homes-uP Single-Family Homes under Pressure', an interdisciplinary research project, funded by the Leibniz Association. 